Volume 4, Number 1, 2018

\title{
Analytical Studies of Coolant Temperature in Solar Panel
}

\author{
Mariana Kasynets ${ }^{*}$, Stepan Shapoval, Khrystyna Kozak, Bohdan Hulai \\ Lviv Polytechnic National University, 12 S. Bandery St., Lviv, 79013, Ukraine
}

Received: March 19, 2018. Revised: May 10, 2018. Accepted: May 17, 2018.

(C) 2018 The Authors. Published by Lviv Polytechnic National University.

\begin{abstract}
An analysis of existing solar heating systems has been carried out. The dependence of the annual flow of solar radiation on the solar panel on the azimuthal angle $\gamma$ and the angle of inclination of the surface, which can be used for studying surfaces with an arbitrary number of orientations, was obtained. The thermal balance for a given solar panel is presented for a certain period of time. Dependences for determining the amount of energy coming from the Sun on each of the surfaces of the solar panel and the amount of accumulated heat by the solar panel was obtained during the research. The losses of convection from the coating of the solar panel and radiation heat losses from the surface of the coating to the environment, as well as thermal losses due to thermal insulation from the back side and the side walls of the heliopanel, are analyzed. The dependence of the coolant temperature in the heliopanel depending on the annual solar radiation inflow and the total heat loss of the heliopanel has been obtained.
\end{abstract}

Keywords: solar collector; heliopanel; solar energy; coolant temperature; thermal accumulation.

\section{Introduction}

Application of solar energy is carried out in three main ways: thermal, thermodynamic and photovoltaic. The advantages of solar energy, in comparison with traditional fuels, are: the inexhaustibility of the energy source and the possibility of using solar energy in virtually all areas of the earth's surface, as well as the possibility of direct conversion of solar energy into heat or electricity and the generation of high-temperature coolants. The solar heating systems are designed to convert solar energy into heat, as well as for its accumulation and supply to the consumer. Obviously, in terms of climatic conditions of Ukraine, open circuits have limited use, because in addition to temperature constraints, such schemes have increased requirements for water quality and in the process of operation the efficiency of solar collectors is significantly reduced. Often, under these conditions, closed circuits with forced circulation of coolant are used, provided that they are connected to the circuit diagram of an electric heater or integrated with a heat-generating device, which allows reducing the cost of hot water supply by $50 \%$ during the year. The main characteristic of solar collectors is the amount of heat that can be obtained from $1 \mathrm{~m}^{2}$ of its surface. There are a large number of circuit designs of these systems, but they all consist of the main elements - heat absorber, coolant battery and heat consumer.

The promising direction of designing energy-saving heat supply systems based on devices that use solar energy is the use of solar panels. The advantages of such structures are that they are the constructive constituent parts of buildings, which significantly reduces their cost compared to solar collectors. Helium panels, for the most part, have a simple design and relatively simple operating conditions, but require careful design and heat storage. The purpose and objectives of the study.

\footnotetext{
* Corresponding author. Email address: mariana.y.kasynets@lpnu.ua
}

This paper should be cited as: M. Kasynets, S. Shapoval, K. Kozak, B. Hulai. Analytical studies of coolant temperature in solar panel. Energy Eng. Control Syst., 2018, Vol. 4, No. 1, pp. 37 - 44. https://doi.org/10.23939/jeecs2018.01.037 


\section{The purpose and objectives of the study}

To substantiate the physical model of thermal processes occurring in the solar panel. In addition, to obtain the dependence of the temperature of the coolant in the heliopanel from the annual flow of solar radiation and heat loss due to thermal insulation from the side and rear parts of the heliopanel.

\section{Analysis of Existing Data}

Solar collectors are divided into flat and concentrating ones, and those in turn are classified into air and liquid ones, high temperature and low temperature ones. In the solar collector, the solar heat flux is converted into heat, which can be selected by the flow of coolant (water, air, antifreeze, etc.), which flows through the heat absorber. The design of solar collectors and their research methods are constantly being improved [1,2].

Actual is the use of combined systems of solar heat supply (Fig.1), since they combine the functions of the main design purpose, as well as the functions of perception and transportation of heat and cold $[3,4]$.

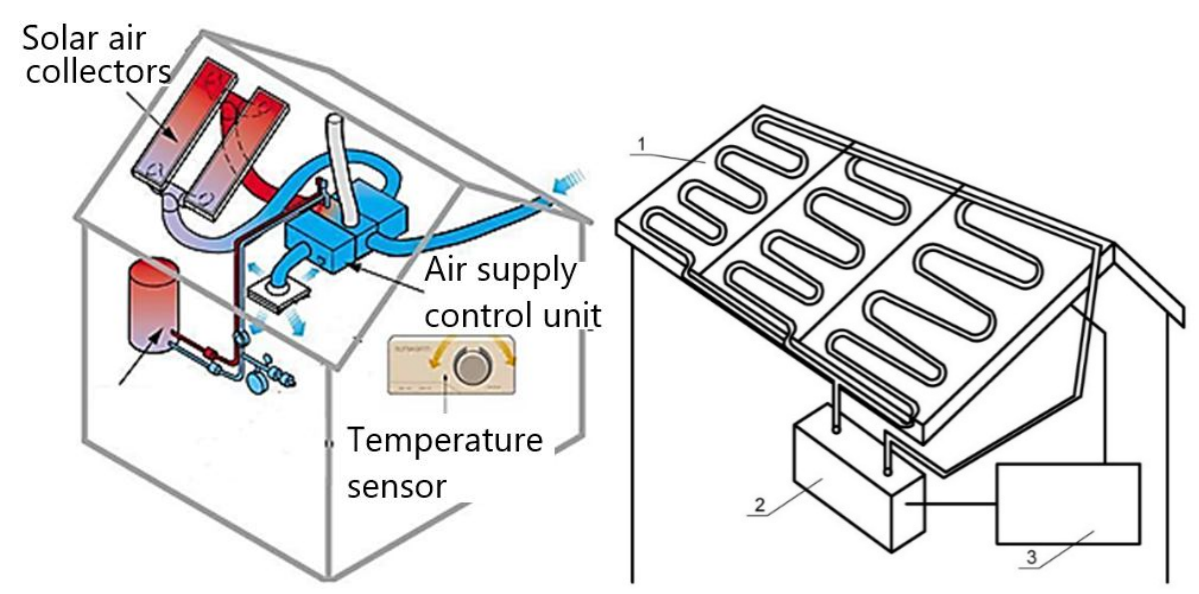

Fig.1. Combined solar heating systems (air and solar roof):

1 - heliopanel; 2 - battery tank; 3 - system automation.

Regarding the roofs, which are divided into cold and warm roofs, in cold roofs, most of which are inclined, the accumulating pipeline is placed under the roof, that is, in the free space between the roof and thermal insulation. The need to install a thermal barrier under the insulating layer in each individual case is conditioned by the proportional ratio of the area of the walls and the area of the roof surface in the attic premises. With a fairly large area of walls, for example, with shield walls with a thermal barrier, there is no need to install a thermal barrier even in the construction of the roof. With a small area of walls in the attic, that is, surfaces with a thermal barrier, it must be installed in roofing structures. The most effective way to erect buildings is to manufacture prefabricated elements with a built-in thermal barrier and accumulating blocks, which are manufactured at the factory and mounted directly on the construction site [5].

In the construction of warm roofs, the thermal barrier, similar to the design of the outer walls, is enclosed in concrete or on the outside of the supporting roof structure in a laying intended for laying a tubular system. Above, there is a layer of thermal insulation, and on it in the laying, which serves as a support for the roofing material, an accumulation pipeline are placed.

Different schemes of combined heat and power supply systems (CHS) with solar panels are known [6, 7]. However, it is unclear whether the design features of the system with solar panels are rational to ensure the maximum efficiency of the heat supply system.

On the basis of the analysis, it can be concluded that there is still a need to develop an effective solar panel design, technological practice of its use in temperate climates, as well as in-depth research on heat transfer for these operating conditions. 


\section{The Experiments and Their Analysis}

To evaluate the efficiency of the solar panel, it is necessary to conduct analytical calculations. The purpose of the analytical calculation is to determine the thermal accumulation properties of the heliopanel and to find the optimal parameters.

Solar energy will be absorbed by heat absorber.The amount of energy it absorbs depends on the intensity of the solar radiation energy entering the surface of the heat absorber. At any time, it can be estimated based on known dependencies [8].

The amount of energy per unit area during the day is from the sum of instant revenue from the moment Sun goes up to its inception. Therefore, the daily amount of energy $Q_{d a y}$ is expressed by the integral of the function $I_{s}(\beta, \varphi, \delta, \gamma, s)$ of a variable $s$ in the range from $-s_{k}$ to $s_{k}$, where $-s_{k}, s_{k}$ is the time angle of the sunrise and sunset:

$$
Q_{d a y}=\int_{-s_{k}}^{s_{k}} I_{s}(\beta, \varphi, \delta, \gamma, s) d s .
$$

where $\beta$ is angle of inclination of the surface in relation to the horizontal plane, deg.; $\delta$ is inclination of the sun, deg.; $\varphi$ is geographical latitude, deg.; $S$ is time angle of the Sun, deg.; $\gamma$ is azimuthal angle of the plane.

The obtained dependence (Fig.2) can be used for studies of surfaces with an arbitrary number of orientations.

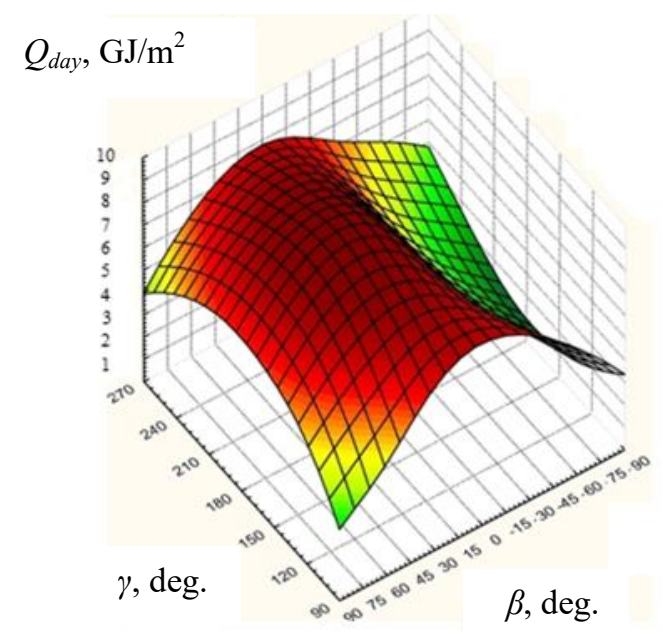

Fig.2. The dependence of the annual solar radiation to the solar panel on the azimuthal angle $\gamma$ and the angle of inclination of the surface $\beta\left(Q_{d a y}=f(\beta, \gamma)\right)$ for $49^{\circ} 50^{\prime} 17^{\prime \prime}$ north latitude (Lviv).

A part of the solar energy will be reflected from the external coating and from the heat absorber. The heat absorbed solar energy will be spent on heating the coolant. At the same time, the process of heating the heat carrier will be accompanied by energy losses due to thermal insulation from the side and rear parts of the solar panel. Heat from the heat absorber through convection and radiation will come to the external coating, and then the convection and radiation will be emitted into the environment. Thermal losses through the lateral and rear parts will prevail over heat conduction (Fig.3).

In the analytical description of the heliopanel, the following assumptions and simplifications were adopted:

1) the temperature of each element in the investigated period was considered constant;

2) the flow of solar energy along the surface of the heat absorber is evenly distributed;

3) the wavelength does not affect the radiating properties of the surfaces;

4) heat is transferred to the environment from the external coating by radiation and convection from the heat absorber;

5) the coolant in the solar panel was considered as a static mass. 


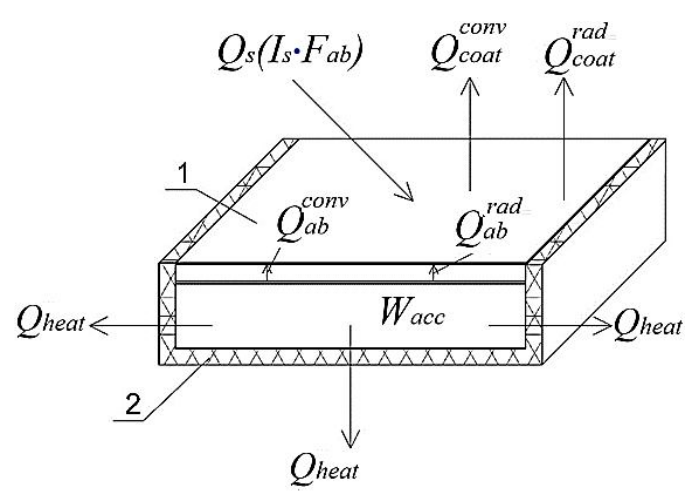

Fig.3. The scheme of thermal balance of the heliopanel: 1- coating of the solar panel; 2 - thermal insulation of the heliopanel.

Analyzing the data [9] heat balance can be written for this heliopaneli over time $\Delta S$ :

$$
W_{\text {acc }}+Q_{\text {coat }}^{\text {conv }} \Delta s+Q_{\text {ins }} \Delta s+Q_{\text {coat }}^{\text {rad }} \Delta s-Q_{s} \Delta s=0,
$$

where $W_{\text {acc }}$ is the amount of heat accumulated over a period of time $\Delta s, \mathrm{~J} ; Q_{\text {coat }}^{\text {conv }}$ is convective losses from the surface of the coating, W; $Q_{\text {ins }}$ is losses due to thermal insulation, W; $Q_{\text {coat }}^{\text {rad }}$ is radiation losses from the surface of the coating, $\mathrm{W} ; Q_{s}$ is the amount of solar energy entering the solar panel, $\mathrm{W}$.

The amount of heat accumulated in the solar panel is determined by the formula $W_{a c c}$ :

$$
W_{\text {acc }}=c m\left(t_{1}-t_{2}\right),
$$

where $c$ is specific heat capacity of the coolant, $\mathrm{J} /(\mathrm{kg} \cdot \mathrm{K}) ; m$ is mass of coolant, $\mathrm{kg} ; t_{1}, t_{2}$ are temperature of the coolant in the beginning and at the end of thermal accumulation, $\mathrm{K}$.

The amount of energy coming from the Sun is defined as the amount of revenue for each of the surfaces of the solar panel $Q_{s}$ :

$$
Q_{c}=A F_{a b} I_{s},
$$

where $A$ is absorption coefficient of solar energy heat absorber; $F_{a b}$ is heat absorber area (Fig. 3 ), $\mathrm{m}^{2} ; I_{s}$ is the intensity of solar energy entering the heat absorber, $\mathrm{W} / \mathrm{m}^{2}$.

Loss by convection from coating to the environment $Q_{\text {coat }}^{\text {conv }}$ :

$$
Q_{\text {coat }}^{\text {conv }}=\alpha_{\text {coat }} F_{\text {coat }}\left(t_{\text {coat }}-t_{\text {amb }}\right),
$$

where $\alpha_{\text {coat }}$ is coefficient of heat transfer from the coating to the environment, $\mathrm{W} /\left(\mathrm{m}^{2} \cdot \mathrm{K}\right) ; F_{\text {coat }}$ is area of surface, $\mathrm{m}^{2}$; $t_{c o a t}$ is temperature of the coating, $\mathrm{K} ; t_{a m b}$ is ambient temperature, $\mathrm{K}$.

Heat losses through thermal insulation on the back side and side walls $Q_{i n s}$ :

$$
Q_{\text {ins }}=\alpha_{\text {ins }} F_{\text {ins }}\left(t_{\text {ins }}-t_{\text {amb }}\right),
$$

where $\alpha_{i n s}$ is coefficient of heat dissipation of thermal insulation, $\mathrm{W} /\left(\mathrm{m}^{2} \cdot \mathrm{K}\right) ; F_{\text {ins }}$ is area of thermal insulation, $\mathrm{m}^{2}$; $t_{\text {ins }}$ is temperature of thermal insulation, $\mathrm{K}$.

Radiation heat losses from the surface of the coating to the environment $Q_{\text {coat }}^{\text {rad }}$ : 


$$
Q_{\text {coat }}^{\text {rad }}=\varepsilon_{\text {rad.c }} C_{o} F_{a b}\left[\left(\frac{t_{\text {coat }}}{100}\right)^{4}-\left(\frac{t_{\text {scies }}}{100}\right)^{4}\right] \text {, }
$$

where $\varepsilon_{\text {rad.c }}$ is relative coefficient of thermal radiation coverage; $C_{0}$ is radiating power of an absolutely black body, $\mathrm{W} /\left(\mathrm{m}^{2} \cdot \mathrm{K}^{4}\right) ; t_{\text {skies }}$ is temperature of the skies, $\mathrm{K} ; F_{\text {amb }}$ is heat absorber area (heat-absorbing plate), $\mathrm{m}^{2}$.

The final value of the temperature of the coolant in the heliopanel:

$$
\begin{aligned}
& t_{2}=t_{1}+\frac{Q_{s} \cdot \Delta s-Q_{c o a t}^{c o n v} \cdot \Delta s-Q_{i n s} \cdot \Delta s-Q_{c o a t}^{r a d} \cdot \Delta s}{c m}= \\
& t_{1}+\frac{\Delta s}{c m} \cdot\left(A \cdot F_{a b} \cdot I_{s}-\alpha_{o a t} \cdot F_{c a t} \cdot\left(t_{c o a t}-t_{a m b}\right)-\right. \\
& -\alpha_{\text {ins }} \cdot F_{\text {ins }} \cdot\left(t_{\text {ins }}-t_{\text {amb }}\right)-\varepsilon_{\text {rad. } .} \cdot C_{0} \cdot F_{a b} \cdot\left[\left(\frac{t_{\text {coat }}}{100}\right)^{4}-\left(\frac{t_{\text {scies }}}{100}\right)^{4}\right] \text {. }
\end{aligned}
$$

Since from the absorber to the coating, and from it to the surrounding environment, heat loss will be carried out by convection, thermal conductivity and radiation, then in this case there will be complicated heat transfer. Heat losses from the heat-receiving part of the solar panel will be determined:

$$
Q_{p-t}=k_{h-t}\left(t_{2}-t_{a m b}\right) F_{a b},
$$

where $k_{h-t}$ is coefficient of heat transfer, $\mathrm{W} /\left(\mathrm{m}^{2} \cdot \mathrm{K}\right)$.

$$
k_{h-t}=\frac{1}{R_{h-t}},
$$

where $R_{h-t}$ is thermal resistance of the heat transfer from the heat absorber to the surrounding environment, $\left(\mathrm{m}^{2} \cdot \mathrm{K}\right) / \mathrm{W}$.

The thermal resistance of the heat transfer from the heat absorber to the environment can be found by the following dependence $[10]$ :

$$
R_{h-t}=\left(\frac{1}{R_{a b}^{\text {conv }}}+\frac{1}{R_{a b}^{\text {rad }}}\right)^{-1}+R_{\text {coat }}+\left(\frac{1}{R_{\text {coot }}^{\text {conv }}}+\frac{1}{R_{\text {coat }}^{\text {rad }}}\right)^{-1},
$$

where $R_{a b}^{c o n v}, R_{a b}^{r a d}$ are respectively, the thermal resistance of heat transfer by convection and radiation from the heat absorber to the air layer, $\left(\mathrm{m}^{2} \cdot \mathrm{K}\right) / \mathrm{W} ; R_{\text {coat }}$ is thermal resistance of the thermal conductivity of the heliopanel coating, $\left(\mathrm{m}^{2} \cdot \mathrm{K}\right) / \mathrm{W} ; R_{\text {coat }}^{\text {conv }}, R_{\text {coat }}^{\text {rad }}$ are respectively, the thermal resistance of heat transfer by convection and radiation from the coating of the heliopanel to the environment, $\left(\mathrm{m}^{2} \cdot \mathrm{K}\right) / \mathrm{W}$.

The thermal balance of thermal accumulation by the given solar panel can be carried out with the following dependence:

$$
m c \frac{d t_{2}}{d S}=Q_{s}-Q_{h-t}-Q_{i n s} .
$$

By substituting expressions (4), (6), (9) into equation (12) the following equation of the thermal balance of the heliopanel is obtained in a differential form:

$$
m c \frac{d t_{2}}{d S}=A F_{a b} I_{s}-\frac{\left(t_{2}-t_{a m b}\right) F_{a b}}{R_{h-t}}-\frac{\left(t_{2}-t_{a m b}\right) F_{i n s}}{R_{i n s}} .
$$

For an analytic solution of equation (13), some notation is necessary:

$$
I_{\text {general }}=A F_{a b} I_{s}
$$




$$
k_{\text {general }}=\frac{F_{a b}}{R_{h-t}}+\frac{F_{i n s}}{R_{i n s}} .
$$

After the separation of variables is obtained:

$$
\begin{gathered}
m c d t_{2}=\left(I_{\text {general }}-k_{\text {general }}\left(t_{2}-t_{\text {aver }}\right)\right) d t, \\
\frac{d t_{2}}{I_{\text {general }}-k_{\text {general }}\left(t_{2}-t_{\text {amb }}\right)}=\frac{d S}{m c} .
\end{gathered}
$$

After integrating expression (17) the following equality is obtained:

$$
-\frac{\ln \left|I_{\text {general }}-k_{\text {general }}\left(t_{2}-t_{\text {amb }}\right)\right|}{k_{\text {general }}}=\frac{S}{m c}+C_{o} .
$$

To find $C_{0}$ the initial condition is used $S=S_{0}$ :

$$
t_{2}\left(S_{o}\right)=t_{\text {aver }}=t_{\text {amb }} \text {. }
$$

As a result, the substitution of the initial conditions is obtained:

$$
\begin{gathered}
-\frac{\ln \left|I_{\text {general }}\right|}{k_{\text {general }}}=\frac{S_{0}}{m c}+C_{o}, \\
C_{o}=\frac{\ln \left|I_{\text {general }}\right|}{k_{\text {general }}}-\frac{S_{0}}{m c} .
\end{gathered}
$$

After substituting (21) to (18) we obtain:

$$
\begin{gathered}
-k_{\text {general }} \frac{\left(S-S_{o}\right)}{m c}=\ln \left|1-k_{\text {general }} \frac{\left(t_{2}-t_{a m b}\right)}{I_{\text {general }}}\right|, \\
1-k_{\text {general }} \frac{\left(t_{2}-t_{a m b}\right)}{I_{\text {general }}}=e^{-k_{\text {general }} \frac{\left(S-S_{0}\right)}{m c}},
\end{gathered}
$$

where $e$ is the basis of natural logarithm.

From equation (23) one can get dependence for temperature determination:

$$
t_{2}=t_{\text {amb }}+\frac{I_{\text {general }}}{\kappa_{\text {general }}}\left(1-e^{-k_{\text {general }} \frac{\left(S-S_{o}\right)}{m c}}\right) .
$$

By substituting expressions (14) and (15) into equation (24), we obtain dependence for determining the temperature of the coolant in the solar panel:

$$
t_{2}=t_{a m b}+\frac{A\left(F_{a b}\right)}{\frac{F_{a b}}{R_{h-t}}+\frac{F_{i n s}}{R_{i n s}}}\left(1-e^{-\left(\frac{F_{a b}}{R_{h-t}}+\frac{F_{i n s}}{R_{i n s}}\right) \frac{\left(S-S_{0}\right)}{m c}}\right) .
$$
obtained:

Expressing $e^{-k_{\text {general }} \frac{\left(\tau-\tau_{0}\right)}{m c}}$ by the MacLoren formula in a linear approximation, the following dependence is 


$$
t_{2}=t_{\text {amb }}+\frac{I_{\text {general }}}{m c}\left(S-S_{o}\right)
$$

Since dependence (26) does not take into account $k_{\text {general }}$, must be written $e^{-\kappa_{\text {general }} \frac{\left(S-S_{0 . \omega}\right)}{m c}}$ by the MacLorena formula in a quadratic approximation:

$$
t_{2}=t_{\text {amb }}+\frac{I_{\text {general }}}{\kappa_{\text {general }}}\left(\frac{k_{\text {general }}}{m c}\left(\tau-\tau_{o}\right)-\left(\frac{k_{\text {general }}}{m c}\right)^{2} \frac{\left(S-S_{o}\right)^{2}}{2}\right) .
$$

Repetition of similar actions in relation to $e^{-k_{\mathrm{ggnenal}} \frac{\left(S-S_{0}\right)}{m c}}$ will increase the complexity of the formula, however, as it follows from the calculations, had little effect on the accuracy of numerical results.

\section{Conclusion}

This article presents the main ways of developing solar energy by combined solar heat supply systems and the areas of their effective use. it analyzes the necessity of installing solar panels as a thermal barrier in building designs. The analytical calculations have been carried out, the results of which have been obtained for the dependence of the annual flow of solar radiation on the solar panel from the azimuthal angle $\gamma$ and the angle of inclination of the surface $\beta\left(Q_{d a y}=f(\beta, \gamma)\right)$ for $49^{\circ} 50^{\prime} 17^{\prime \prime}$ north latitude (Lviv) can be used to study surfaces with an arbitrary number of orientations. Also, the dependence of the coolant temperature in the solar panel is obtained from the annual solar radiation on the surface of the solar panel and heat loss due to the thermal insulation from the side and rear parts of the solar panel.

\section{References}

[1] Misak Y. S., Voznyak O.T., Datsko O.S., Shapoval S.P. (2014) Solar Energy: Theory and Practice. Monograph. Lviv Polytechnic Publishing House, 340 p. (in Ukrainian)

[2] Voznyak O., Pona O., Eltman A., Shapoval S., Spodyniuk N (2015) Method of determining the efficiency of heliocollector in system with forced circulation of coolant. Scientific and technical collection "Energy Efficiency in Construction and Architecture" Kiev National University of Civil Engineering and Architecture. Iss. 7, Kyiv, p. 10-16. (in Ukrainian)

[3] Pona O.M., Misak Y. S., Shapoval S.P., Datsko O.S. (2016) The efficiency of using a solar collector combined with the roof of the house in the solar heat supply system. Theory and practice of construction. Bulletin of the National University Lviv Polytechnic, No. 844, p. 164-168. (in Ukrainian)

[4] Kozak Ch., Savchenko O., Zhelykh V. (2016) Analysis of Heat Flow Distribution in the Room with Installed Solar Air Heater. Cieptownictwo, Ogrzewnictwo, Wentylacja: miesięcznik Polskiego Zrzeszenia Inżynierów i Techników Sanitarnych, T 45, nr, 9, p. 359-362. doi: http://yadda.icm.edu.pl/baztech/element/bwmeta1.element.baztech-8832c7f0-5cc3-4438-81d4-fe023558704d.

[5] Neumann F., Patschke M., Schoennenbeck M. (2009) Heliothermal flat collector module having a sandwich structure. Patent. 7610911 USA, N 10/530384, has published 11.03.2009.

[6] Voznyak O., Pona O., Shapoval S., Kasynets M. (2014) Efficiency of Solar roof with transparent cover for heating supply of buildings. Budownictwo o 16 zoptymalizowanym potencjale energetycznym. Construction of optimized energy potential, Częstochowa, 2(14), p. 117124. doi: http://yadda.icm.edu.pl/baztech/element/bwmeta1.element.baztech-3d1b22a9-9e0a-4acf-9a87-d26b597f1b2f

[7] Kasynets M. YE. (2012) Efficiency of work of solar panels of various designs. Theory and practice of construction. Bulletin of the National University Lviv Polytechnic, No.737, p. 139-143. doi: http://ena.lp.edu.ua:8080/handle/ntb/16639 (in Ukrainian)

[8] Brinkworth, B.J. (1976) Solar energy for man. Transl. from English Oglobleva V.N, Moscow, p. 291 (in Russian)

[9] Kasynets M. YE. (2012) Investigation of efficiency of solar panels. Theory and practice of construction. Bulletin of the National University Lviv Polytechnic, No. 742, p. 99-105. http://ena.lp.edu.ua:8080/handle/ntb/17995 (in Ukrainian)

[10] Novakivskyi Y. V. Improvement of efficiency of solar energy use in the combined industrial heat supply systems: abstract of thesis for sci. degr. of Cand. of Techn. Sci.: spec. 05.14.06 "Technical thermophysics and industrial thermal power engineering " / Y. V. Novakivskyi. Odessa, 2004. - 22 p. (in Ukrainian)

[11] Shaefeev A. I. (1991) Simulation of solar heating systems for an individual home. Helio technology, No. 2, p. 55-59. (in Russian) 


\title{
Аналітичні дослідження температури теплоносія в геліопанелі
}

\author{
Мар'яна Касинець, Степан Шаповал, Христина Козак, Богдан Гулай \\ Націіональний університет «Львівська політехніка», вул. С. Бандери 12, Львів, 79013, Украӥна
}

\begin{abstract}
Анотація
Виконано аналіз існуючих систем сонячного теплопостачання. Отримано залежність річного надходження сонячної радіації на геліопанель від азимутального кута $\gamma$ і кута нахилу поверхні, яка може бути використана для дослідження поверхонь із довільною кількістю орієнтацій. Представлено тепловий баланс для даної геліопанелі за певний проміжок часу. Досліджено залежності для визначення кількості енергії, що надходить від Сонця на кожну із поверхонь геліопанелі та кількості тепла, закумульованого геліопанеллю. Проаналізовано втрати конвекцією від покриття геліопанелі та радіаційні тепловтрати із поверхні покриття в навколишнє середовище, а також тепловтрати через теплоізоляцію із тильної сторони та бокових стінок геліопанелі. Отримано залежність температури теплоносія в геліопанелі від річного надходження сонячної радіації та сумарних тепловтрат геліопанелі.
\end{abstract}

Ключові слова: сонячний колектор; геліопанель; сонячна енергія; температура теплоносія; термоакумуляція. 